\title{
NOISE ANALYSIS TO EVALUATE CHICK THERMAL COMFORT
}

\author{
Daniella Jorge de Moura ${ }^{1 *}$; Irenilza de Alencar Nääs ${ }^{1}$; Elaine Cangussu de Souza Alves²; \\ Thayla Morandi Ridolfi de Carvalho²; Marcos Martinez do Vale³; Karla Andrea Oliveira de \\ Lima $^{3}$ \\ ${ }^{1}$ UNICAMP/FEAGRI - Depto. de Construções Rurais e Ambiência, C.P. 6011 - 13083-930 - Campinas, SP - \\ Brasil. \\ ${ }^{2}$ UNICAMP/FEAGRI - Graduanda em Engenharia Agrícola. \\ ${ }^{3}$ UNICAMP/FEAGRI - Programa de Pós-Graduação em Engenharia Agrícola. \\ *Corresponding author <daniella.moura@agr.unicamp.br>
}

ABSTRACT: The relationship between thermal environment and chick performance has widely been evaluated, however the consideration that the assessment of the comfort may be estimated by interpreting both amplitude and frequency of bird vocalization under tropical housing conditions is a new concept. This research had as objective of estimating thermal comfort for chicks during the heating phase using this new concept. An experiment was carried out inside a climate controlled chamber (A) for establishing the behavioral pattern related to environmental temperature limits. Forty five chicks were reared inside a $2.3 \mathrm{~m}^{2}$ box. A video camera was placed $2.0 \mathrm{~m}$ above the birds and the images were captured and registered in a computer. From the pattern determined in the controlled chamber an evaluation of the results was proceeded in a commercial broiler farm (experiment B) using similar bird density in order to validate the data. Environmental temperature, and both amplitude and frequency of the vocalizations of the chick group reared under heating were continuously recorded in both experiments. A correlation between group behavioral pattern and their vocalization, was found, evaluated not only by the noise amplitude but also by the noise frequency spectrum. When the thermal inertia is maintained by adequate use of curtains the birds vocalized less which is coincident with the low sudden variation of the temperature of the environmental. It was possible to estimate the thermal comfort for chicks at the heating stage by recording the amplitude and the frequency of the noise emitted by the reared group.

Key words: broiler production, analysis of signals, thermal environment, behavior

\section{ANÁLISE DE RUÍDO PARAAAVALIAÇÃO DO CONFORTO TÉRMICO DE PINTINHOS}

RESUMO: A relação entre o ambiente térmico e o desempenho de pintinhos tem sido estudada, entretanto a consideração de que a medida de conforto térmico possa ser estimada pela interpretação da amplitude e da freqüência da vocalização, em condições tropicais de alojamento é um conceito novo. Esta pesquisa teve como objetivo estimar uma medida de bem-estar térmico para pintinhos em fase de aquecimento, pela medida de amplitude e freqüência do ruído emitido pelo grupo alojado. Inicialmente foi feito um experimento em câmara climática (A), para se estabelecer padrões de comportamento a partir de limites de temperatura ambiental. Foram alojados 45 pintos em um box de 2,3 $\mathrm{m}^{2}$. Uma câmera foi colocada a 2,0 $\mathrm{m}$ acima das aves e a captura das imagens foi registrada em um computador. A partir dos padrões determinados no primeiro experimento, foi feita uma avaliação desses resultados em uma granja comercial (experimento B) utilizando densidade de aves semelhante, de maneira a possibilitar uma validação. Foram medidas continuamente: a temperatura ambiental e a amplitude e freqüência de ruídos, do grupo de pintos alojados durante a fase de aquecimento em ambos experimentos. Houve correlação entre um padrão de comportamento de agrupamento e a vocalização, medida não somente pela amplitude do ruído do grupo, mas também pelo espectro da sua freqüência. Na etapa de validação observou-se que, mantida a inércia térmica pelo uso adequado de cortinas, as aves vocalizam menos, coincidentemente com a baixa variação súbita de temperatura. Foi possível estimar o bem-estar térmico de pintinhos na fase de aquecimento pelo registro da amplitude e freqüência de ruído do grupo alojado.

Palavras-chave: produção de frangos de corte, análise de sinais, ambiente térmico, comportamento 


\section{INTRODUCTION}

Brazilian poultry business represents $2 \%$ of the country's GNP; it has grown around $10 \%$ per year in the last three decades, and employs around two million workers (Mendes \& Saldanha, 2004). Data on thermal comfort for young broilers are well documented in the literature and show that either the excess or the lack of heat during the first three weeks may lead to near $12 \%$ of body weight loss, affecting physiological variables such as heart beats and blood pressure (Vest, 1997; Hel et al., 1992; Macari et al., 1994; Dozier \& Donald, 2001; Moraes et al., 2002).

Animal comfort assessment has widely been considered and several ways of measuring were proposed such as: physical health, behavior, and level of injuries (Moberg, 1985; Barnett \& Hemsworth, 1990; Dawkins, 1990; Broom \& Johnson, 1993; Borell, 1995). Animal vocalization literature advocates that it may be a useful tool for assessing animal comfort as it acts in a non-invasive way besides being a precise and objective technology (Jurgens, 1979; Weary \& Fraser, 1995; Schrader \& Todt, 1998; Mulligan et al., 2002).

Approximately thirty distinct sounds are already registered among the extensive repertoire of young and old broilers and chickens (Collias \& Joos, 1953; Guhl, 1968; Wood-Gush, 1971; Mills \& Wood-Gush, 1983; Zimmerman \& Koene, 1998). The methodology includes distinct noise recording technology, however, available data often depart from specific patterns making comparisons between them quite difficult (Marx et al., 2001). When comparing chicken submitted to feeding frustration Zimmerman \& Koene (1998) found that distinct genetic layer strain vocalized in a different way during stress exposition and the noise emitted was proportional to the suffering, reaching the duration up to 4s. Marx et al. (2001) were able to detect the vocalization of frustration, when isolating young broilers inside an anechoic chamber ${ }^{1}$.

This research aimed to identify and measure correlation between the thermal environment and to vocalization during the heating phase of chicks for assessing thermal comfort based on the measurement of noise amplitude and frequency.

\section{MATERIAL AND METHODS}

The experiment was carried out in two phases: first a pilot experiment (A) was made inside a temperature controlled chamber in order to monitor and register the vocalization of the chicks in known envi- ronmental conditions, warm $\left(29-24^{\circ} \mathrm{C}\right)$ and cold $(23-$ $15,62^{\circ} \mathrm{C}$ ); and a second experiment (B) in which the previous results from the first experiment were validated by monitoring and recording the same data inside a commercial farm.

Experiment A: was carried out inside a temperature controlled chamber in Campinas, Sao Paulo State (SP), Brazil, (22 $54^{\prime}$ S, $47^{\circ} 03^{\prime}$ W) using 45 chicks from the Cobb $^{\circledR}$ breed, 14 days old, housed inside a box of 1.9 $\times 1.2 \mathrm{~m}^{2}$, having an initial phase manual feeder and drinker, (Figure 1). Data were recorded after the birds were acquainted with the new environment for two consecutive days. A cardioid microphone placed 0.2 $\mathrm{m}$ above the birds and connected to a computer was used to register digitally and continuously the emitted noises. Concomitantly and placed at the same height, a data logger $\mathrm{HOBO}^{\circledR}$ registered continuously the air temperature. Image frames were recorded during the experiment using a video camera Top Cam ${ }^{\circledR}$ installed $2.0 \mathrm{~m}$ above the box, also connected to a computer.

The degree of flock swarm was divided into three categories: apart, slightly apart, and crowded. Vocalization pattern data were classified into three categories: none, few, and frequent. To analyze the noise frequency spectrum two filter stages were necessary using the software Cool Edit ${ }^{\circledR}$ and Audacity ${ }^{\circledR}$.

Experiment B: was carried out in a commercial broiler farm located at Rio Claro, SP, Brazil, $\left(47^{\circ} 37^{\prime} \mathrm{W}\right.$, $22^{\circ} 24^{\prime}$ S) with predominant winds SE. The approximate density used in the experiment was the same as in experiment $\mathrm{A}$, rearing 75 chicks inside a closed environment equivalent to $3 \mathrm{~m}^{2}$ inside the farm house. Drinkers were of the nipple kind and feeders were au-

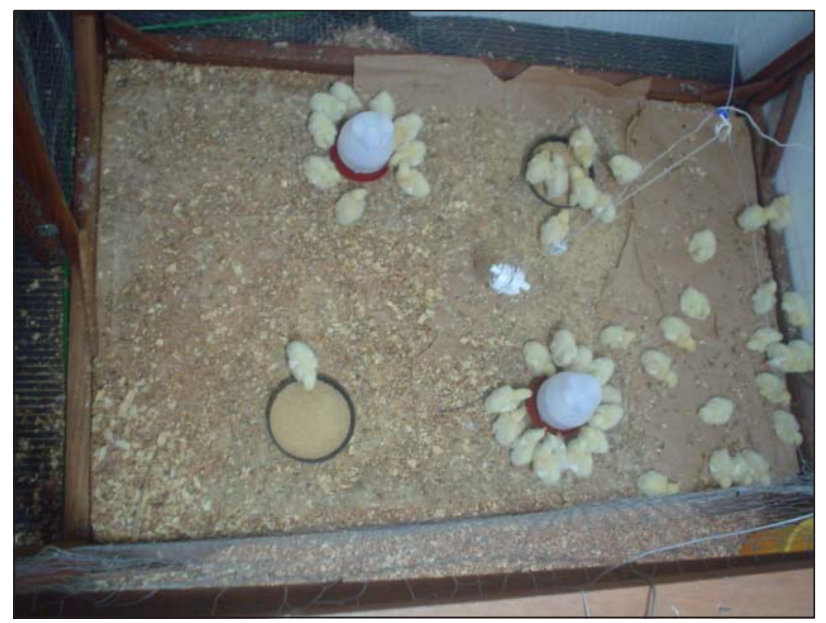

Figure 1 - Video camera picture used to register behavior data of the chicks inside the box.

${ }^{1}$ Chamber with complete acoustic isolation 
tomatic, and the heater used gas as fuel. Vocalization was recorded using a cardioid microphone placed above the birds, and the noise was recorded digitally every minute, and data were stored in a computer. Temperature was recorded using the data logger $\mathrm{HOBO}^{\circledR}$ placed $0.2 \mathrm{~m}$ above the birds. Data were recorded continuously during two days.

Statistical analysis of data from both experiments was made using the Fisher test and was processed using the software SAS (1992).

The analysis of the association: temperature, swarm degree, and chicks vocalization, was made by the Fisher test. This specific statistical test is recommended when the amount of data is relatively small, having been extensively used in the literature in similar conditions (Beecher et al., 2000 and Wollerman \& Wiley, 2001).

\section{RESULTS AND DISCUSSION}

The fisher test showed a strong association between temperature and degree of swarm (Table 1) for experiment A $(p<0.001)$, in agreement with Vest (1997), Macari (1996), and Moraes et al. (2002).

Regarding the swarm percentage and the intensity of vocalization, there was a high correlation $(p<0.001)$ between both variables (Table 2). While apart and in thermal comfort chicks vocalize more than when exposed to cooler temperatures. This may indicate that the vocalization is a way of calling attention to a specific aggressive situation, as pointed by Marx et al. (2001).

From the time of exposure to both extremes of temperature it was possible to identify two levels of vocalization amplitude related to thermal comfort

Table 1 - Relation between the degree of flock swarm, and temperature exposure inside the controlled temperature chamber (Experimental A).

\begin{tabular}{lccc}
\hline \multirow{2}{*}{ Temperature range } & \multicolumn{3}{c}{ Degree of flock swarm } \\
\cline { 2 - 4 } & crowded & slightly apart & apart \\
\hline${ }^{\circ} \mathrm{C}$ & ---10 & 70 & 30 \\
$17-23$ & 0 & 0 & 100 \\
\hline $24-29$ & 0 & 0 & 0 \\
\hline
\end{tabular}

(Figure 2) and thermal distress (Figure 3). The two amplitude levels for both conditions (comfort and distress) showed similar pattern when compared between them in same condition.

The size of the noise frequency spectrum was classified by observing all recorded data, and selecting as small $(500-2700 \mathrm{~Hz})$, average $(2700-3600$ $\mathrm{Hz})$ and large $(>3600 \mathrm{~Hz})$. The value given to each range was found by extracting the smallest value from the highest one using the software Audacity ${ }^{\circledR}$. Figure 4 and 5 display the frequency analysis for both vocalization responses to thermal comfort and thermal distress respectively. By analyzing the frequency, it is clear that the thermal distress can be easily detected by its shape, as suggested by Mills \& Wood-Gush (1983) and Marx et al. (2001).

When analyzing the data of flock swarm pattern and noise frequency spectrum using the Fisher test a statistical correlation ( $p=0.02$ ) was found between both variables (Table 3). The increase in chick swarm was directly related to the increase in the vocalization frequency. There was a decrease in the noise amplitude when temperatures were below comfort with a consequent lower variation within the amplitudes recorded (Figure 2). On the other hand, when the flock swarm dispersed there was an increase in the noise amplitude variation (Figure 3).

Data shown in Table 3 were applied to experiment B. Recorded environmental temperature data from the commercial farm inside the chick cell had a range from 24.98 to $30.20^{\circ} \mathrm{C} \pm 1.3^{\circ} \mathrm{C}$ during fourteen eight consecutive hours (Figure 6) maintaining relatively constant and closer to the lowest temperature in the morning and to the highest temperatures in the afternoon. The temperature limits in the housing were within the warm limit, as mentioned in Table 1.

To induce a decrease in temperature the heat source was turned off, however this still did not induce enough impact in the vocalization behavior, even though several authors established that sudden changes in the environmental temperature may lead to changes in the vocalization pattern (Guhl, 1968; Wood-Gush, 1971; Mills \& Wood-Gush, 1983; Zimmerman et al., 2000). The variation in the environmental temperature did not take place in a sudden way since the curtain

Table 2 - Results of the relation between vocalization of chicks and pattern of swarm.

\begin{tabular}{|c|c|c|c|c|}
\hline \multirow{2}{*}{ Temperature } & \multirow{2}{*}{ Degree of flock swarm } & \multicolumn{3}{|c|}{ Vocalization } \\
\hline & & none & few & frequent \\
\hline${ }^{\circ} \mathrm{C}$ & & $-\ldots-$ & $-\%$ & 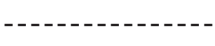 \\
\hline 15.62 to 16 & crowded & 76 & 0 & 0 \\
\hline 17 to 23 & slightly apart & 41 & 9 & 0 \\
\hline 24 to 29 & apart & 26 & 24 & 6 \\
\hline
\end{tabular}


Table 3 - Results of the Fisher test in relation to the incidence of frequency spectrum and flock swarm pattern.

\begin{tabular}{lccc}
\hline & \multicolumn{3}{c}{ Frequency spectrum range (Hz) } \\
\cline { 2 - 4 } & $500-2700$ & $2700-3600$ & $>3600$ \\
\hline Chick behavior & \multicolumn{4}{c}{ Flock swarm (\%) } \\
\hline crowded & 12 & 24 & 65 \\
slightly apart & 28 & 43 & 29 \\
apart & 42 & 30 & 28 \\
\hline
\end{tabular}

cell maintained the thermal isolation, increasing the inertia of the room temperature avoiding sudden heat loss, and consequent cooler environment.

Data from sound pressure (dB) and fundamental frequency $(\mathrm{Hz})$ were applied to the software Audacity ${ }^{\circledR}$, and the spectrum analysis is shown in Figure 7.

Variables related to noise were practically constant during the farm experiment varying only in the

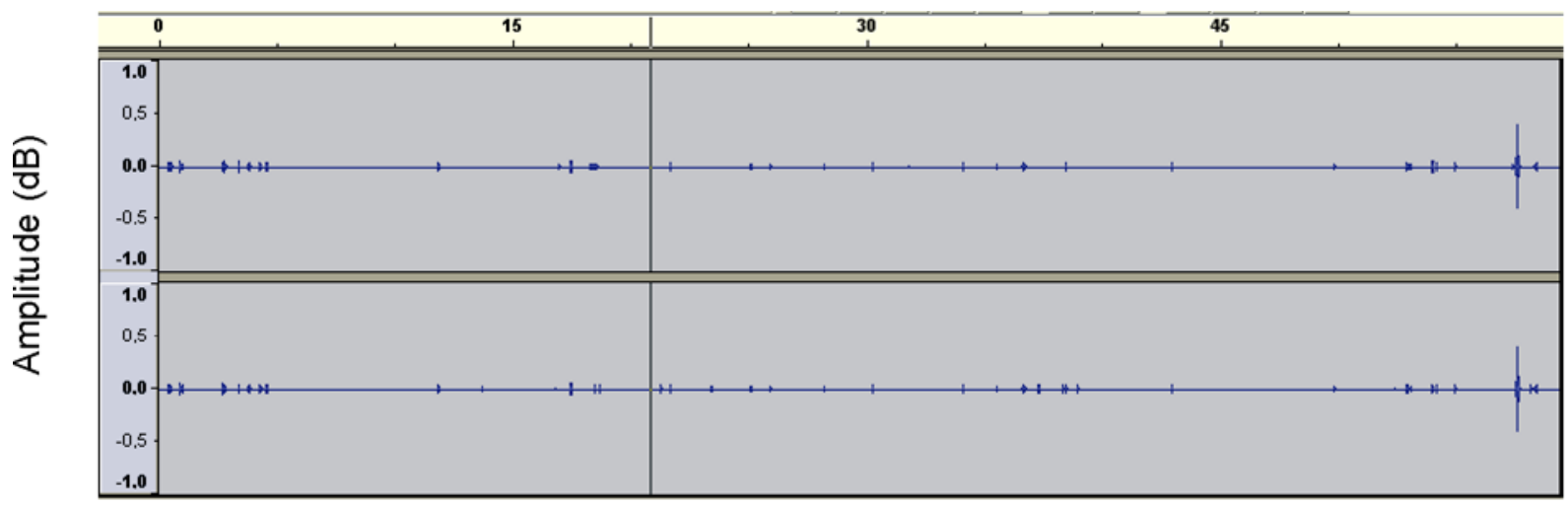

Time (s)

Figure 2 - Noise amplitude along time of chick exposure to thermal comfort.

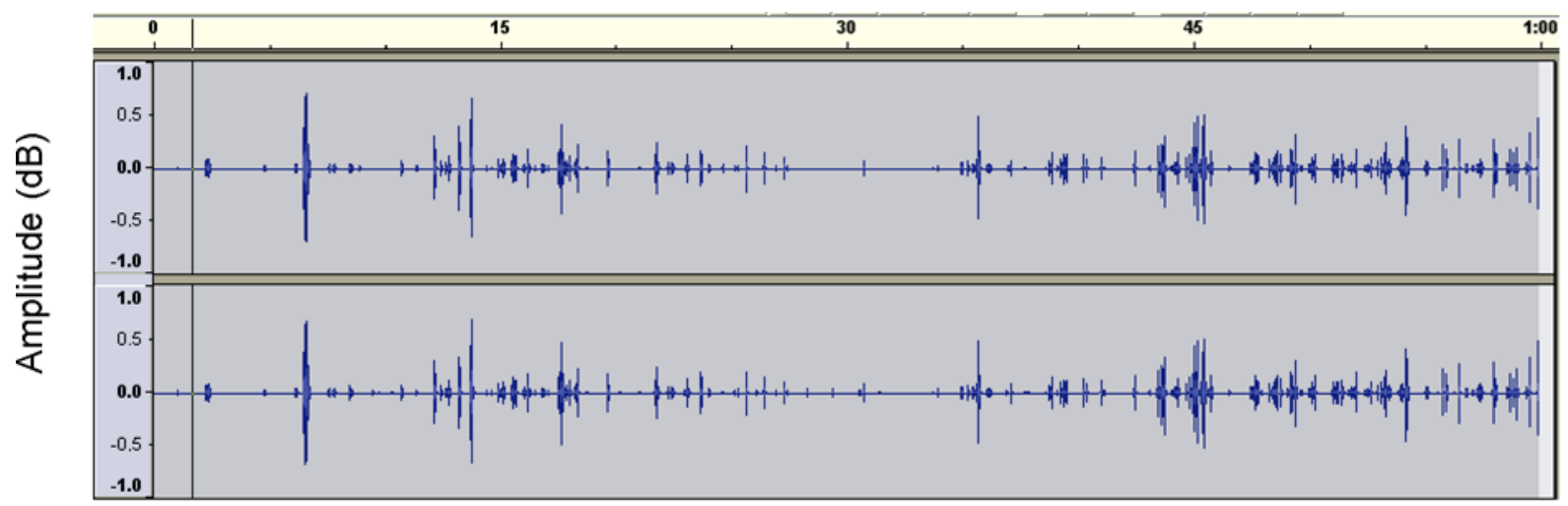

Time (s)

Figure 3 - Noise amplitude along the time of chick exposure to thermal distress.

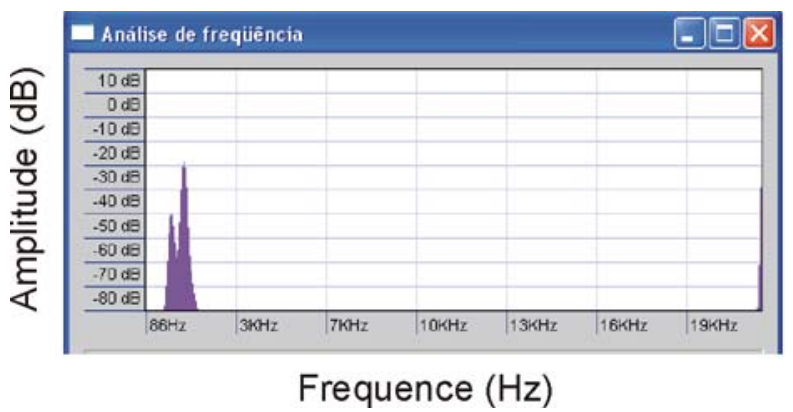

Figure 4 - Noise frequency spectrum display during thermal comfort exposure.

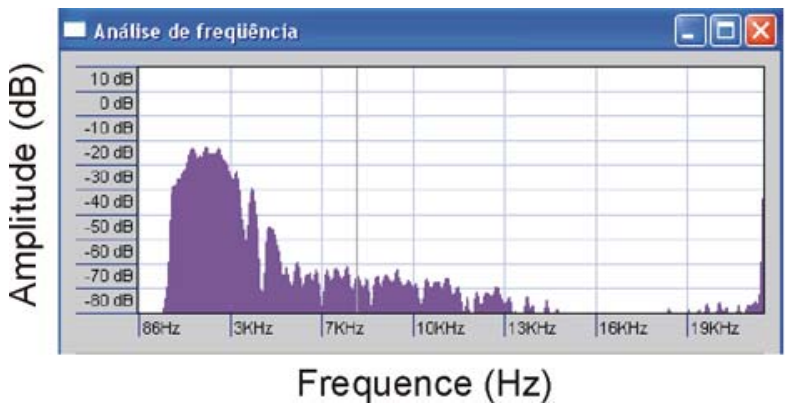

Figure 5 - Noise frequency spectrum display during thermal distress exposure. 


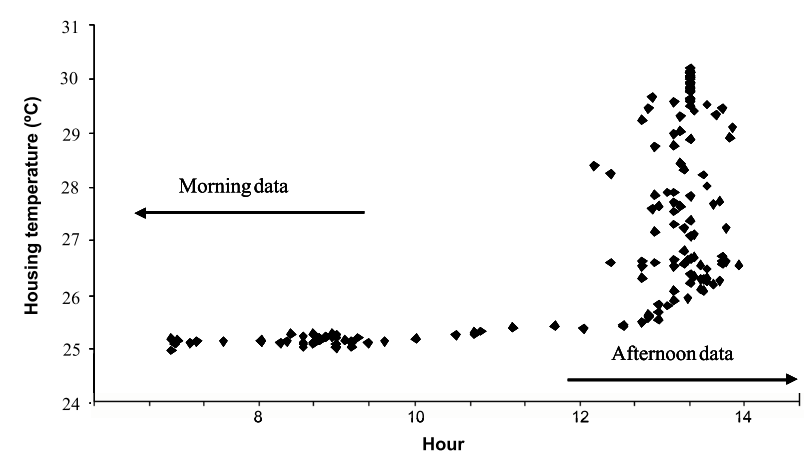

Figure 6 - Environmental temperature records distribution along the daytime in a commercial broiler farm during the heating period.

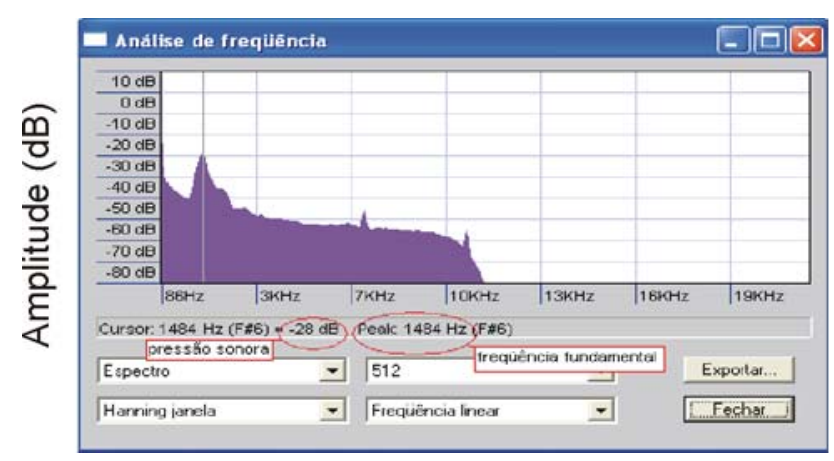

Figure 7 - Spectrum of vocalization frequencies and sound pressure display of the broiler farm.

level of 3\%. The extent of vocalization recorded was classified as stable for all noise samplings. Even applying filters it was not possible to find a correlation between the chick vocalization and the slight environmental change in temperature.

Visual observation showed that the chicks were also kept in a normal distribution pattern enhancing the findings in the experiments inside the controlled environment, that vocalization generally occurs when there is unbalanced heat exchange causing heat distress.

\section{CONCLUSIONS}

In this innovative way of assessing chick thermal comfort, correlating environmental temperature with behavior and vocalization, it was found that when chicks are exposed to thermal comfort they have a tendency to vocalize less and this is associated to the flock maintained apart. As the temperature decreases the vocalization is increased in frequency up to a complete flock swarm, when the chicks warm up by gathering and consequently reducing heat loss of the flock. At this pattern the frequency of vocalization stabilized to an equivalent to thermal comfort exposure. The validation experiment in the broiler farm showed that the slight change in environmental temperature did not induce significant change in the vocalization, due to the large thermal inertia of the rearing environment.

\section{ACKNOWLEDGEMENTS}

To CNPQ and FAPESP for providing financial support to this research, and Granja Matuetê for allowing data collection.

\section{REFERENCES}

BARNETT, J.L.; HEMSWORTH, P.H. The validity of physiological and behavioural measures of animal welfare. Applied Animal Behaviour Science, v.1, p.177-187, 1990.

BEECHER, M.D.; CAMPBELL, E.S.; BURT, J.M.; HILL, C.E.; NORDBY, C.J. Song type matching between neighboring sparrows. Animal Behaviour, v.59, p.10, 2000.

BORELL, E. van. Neuroendocrine integration of stress and significance of stress for the performance of farm animals. Applied Animal Behaviour Science, v.44, p.219-227, 1995.

BROOM, D.M.; JOHNSON, K.G. Stress and animal welfare. London: Chapman and Hall, 1993. 310p.

COLLIAS, N.E.; JOOS, M. The spectographic analysis of sound signals in the domestic fowl. Behaviour, v.5, p.175-188, 1953.

DAWKINS, M.S. From an animal's point of view: motivation, fitness, and animal welfare. Behavioral and Brain Sciences, v.13, p.1-61, 1990.

DOZIER, W.A.; DONALD, J. Keys to successful brooding. Auburn: Auburn University/Poultry Engineering and Economics Department, 2001. p.42. (Extension Bulletin).

GUHL, A.M. Social behavior of the domestic fowl. Transactions of Kansas Academy of Sciences, v.71, p.379-384, 1968.

HEL, W. van der; VERSTERGEN, M.W.A.; PIJLS, L.; KAMPEN, M. van. Effect of two day temperature exposure of neonatal broiler chicks on growth performance and body composition during two weeks at normal conditions. Poultry Science, v.71, p.2014-2021, 1992.

JURGENS, U. Vocalization as an emotional indicator: a neuroethological study in the squirrel monkey. Behaviour, v.69, p.88-117, 1979.

MACARI, M.; FURLAN. R.L.; GONZALES, E. Fisiologia aviária aplicada a frangos de corte. Jaboticabal: FUNEP/UNESP, 1994. 296p.

MACARI, M. Conforto ambiental para aves: ponto de vista do fisiologista. In: SIMPÓSIO GOIANO DE AVICULTURA, 2., Goiânia, 1996. Anais. Goiânia: UFG/AGA, 1996. p.57-60.

MARX, G.; LEPPELT, J.; ELLENDORFF, F. Vocalisation in chicks (Gallus gallus dom.) during stepwise social isolation. Applied Animal Behaviour Science, v.75, p.61-74, 2001.

MENDES, A.A.; SALDANHA, E.S.P.B. Produção de frangos de corte. In: MENDES, A.A.; NÄÄS, I.A.: MACARI, M. (Ed.) A cadeia produtiva de carne de aves no Brasil. Campinas: FACTA, 2004. p.1-22.

MILLS, A.D.; WOOD-GUSH, D.G.M. Genetic analysis of frustration responses in the fowl. Applied Animal Ethology, v.9, p.8889, 1983.

MORAES, V.M.B.; MALHEIROS, R.D. FURLAN, R.L.; BRUNO, L.D.G.; MALHEIROS, E.B.; MACARI, M. Effect of environmental temperature during the first week of brooding period on broiler chick body weight, viscers and bone development. Revista Brasileira de Ciência Avícola, v.4, p.1-8, 2002.

MOBERG, G.P. Biological response to stress: key to assessment of animal wellbeing? In: MOBERG, G.P.; BROOM, D.M.; JOHNSON, K.G. (Ed.) Stress and animal welfare. London: Chapman and Hall, 1985. p.27-49. 
MULLIGAN, B.E.; BAKER, S.C.; MURPHY, M. R. Vocalizations as indicators of emotional stress and psychological well being in animals. Animal Welfare Informative, v.5, p.3-4, 2002.

SAS. Statistical Analysis System: release 6.08 (software). Cary: SAS Institute, 1992. 620p.

SCHRADER, L,; TODT, D. Vocal quality is correlated with levels of stress hormones in domestic pigs. Ethology, v.104, p.859876, 1998.

VEST, L.R. Environmental factors to consider when brooding chicks. Cooperative Extension Service, Bulletin 855. College of Agricultural and Environmental Science, University of Georgia, Athens. 1997.

WEARY, D.M.; FRASER, D. Calling by domestic piglets: reliable signals of need? Animal Behaviour, v.50, p.1047-1055, 1995.

WOOD-GUSH, D.G.M. The behaviour of the domestic fowl. London: Heineman, 1971. 231p.
WOLLERMAN, L.; WILEY H.R. Background noise from a natural chorus alters female discrimination of male calls in a neotropical frog. Animal Behaviour, v.62, p.8, 2001.

ZIMMERMAN, P.H.; KOENE, P. The effect of frustrative nonreward on vocalisations and behaviour in the laying hen, Gallus gallus domesticus. Behavior Processes, v.44, p.7379, 1998.

ZIMMERMAN, P.H.; KOENE, P.; HOOFF, J.A.R.A.M. van. The vocal expression of feeding motivation and frustration in the domestic laying hen, Gallus gallus domesticus. Applied Animal Behaviour Science, v.69, p.265-273, 2000.

Received December 18, 2006

Accepted November 29, 2007 